\title{
Immediate-early gene expression in the amygdala following footshock stress and contextual fear conditioning
}

\author{
Jeffrey B. Rosen ${ }^{\text {a, * }}$, Michael S. Fanselow ${ }^{\text {b }}$, Stacey L. Young ${ }^{\mathrm{c}}$, Martina Sitcoske ${ }^{\mathrm{d}}$, Stephen Maren ${ }^{\mathrm{e}}$ \\ a Department of Psychology, University of Delaware, Newark, DE 19716 USA \\ ${ }^{\mathrm{b}}$ Department of Psychology, University of California, Los Angeles, CA 90095 USA \\ ${ }^{\mathrm{c}}$ Department of Psychology, University of Vermont, Burlington, VT 05405 USA \\ ${ }^{d}$ Biological Psychiatry Branch, National Institute of Mental Health, Bethesda, MD 20892 USA \\ ${ }^{\mathrm{e}}$ Department of Psychology, University of Michigan, Ann Arbor, MI 48109, USA
}

Accepted 17 March 1998

\begin{abstract}
This study investigated the increase in expression in the amygdala of 2 immediate-early genes, c-fos and NGFI-A, following contextual fear conditioning. The immediate-shock freezing deficit paradigm was used to compare rats that received footshock after exploring a context to rats that received footshock immediately after placement in the chamber. The former procedure produces contextual fear conditioning while the latter does not. Rats were either handled (handled group), placed in a test chamber without receiving footshock (context-no-footshock group), received footshock immediately upon being placed in the chamber (immediate-footshock group), or received footshock after a 1 min delay (delayed-footshock group). Only the delayed-footshock group displayed a fear response (freezing behavior). Rats were sacrificed either $15 \mathrm{~min}$ after the experience or after a retention test $24 \mathrm{~h}$ later. The c-fos mRNA was increased in the medial nucleus of the amygdala in all of the groups that were placed in the test chamber. However, rats that received footshock (immediate- and delayed-footshock groups) had greater levels of c-fos mRNA expression than rats of the context-no-footshock group. The c-fos mRNA expression in the immediate- and delayed-footshock groups did not differ. However, after the retention test, the expression of c-fos mRNA in the medial nucleus of the amygdala did not differ between groups. In contrast to c-fos, NGFI-A mRNA expression in the lateral nucleus of the amygdala was greater in the delayed-footshock group than the handled and context-no-footshock groups 15 min after the footshock. This elevation in NGFI-A mRNA was not seen in the immediate-footshock group. This suggests that NGFI-A mRNA in the lateral nucleus of the amygdala may play a role in contextual fear conditioning. (C) 1998 Elsevier Science B.V. All rights reserved.
\end{abstract}

Keywords: c-fos; NGFI-A; zif268; Amygdala; Fear; Conditioning

\section{Introduction}

In the last several years, a neuroanatomical circuit of individual nuclei within the amygdala has been shown to be important for fear conditioning [9,24]. A serial circuit from the lateral nucleus to the basolateral nucleus and finally to the central nucleus of the amygdala has been delineated and is necessary for the expression of conditioned fear. Lesion and glutamate antagonist studies have demonstrated that the lateral, basolateral and central nuclei of the amygdala are all necessary for either acquisition or

\footnotetext{
* Corresponding author. 220 Wolf Hall, Department of Psychology, University of Delaware, Newark, DE 19716. Fax: +1-302-831-3645; E-mail: jrosen@udel.edu
}

expression of fear conditioning [6,13,15,18,20,24,26,27]. The lateral and basolateral nuclei may be important for the formation of associations between conditioned and unconditioned aversive stimuli $[9,23,24]$. Stimulation and neuroanatomical tracing studies also suggest that the central nucleus is the major output pathway to many subcortical regions that mediate fear-related behaviors such as freezing, startle, and autonomic responses $[16,17,19,22,35,36,39,40]$.

In addition to studies with lesions, stimulation and glutamate antagonists, several reports using markers of brain activation also suggest that the amygdala is activated during the acquisition and expression of fear conditioned responses. LeDoux et al. [25] demonstrated that cerebral blood flow increases in the amygdala in response to audi- 
tory conditioned fear stimulus in rats. Using Northern blot analysis of c-fos mRNA, an immediate-early gene (IEG) that can be exploited as a neuronal activity marker, Campeau et al. [7] found an elevation in c-fos mRNA in the amygdala following both footshock and the contextual cues associated with footshock. However, Smith et al. [37], using in situ hybridization of c-fos mRNA expression, found expression in the endopyriform nucleus, but not in the amygdala. Furthermore, Fos protein expression has been shown to be expressed in the medial nucleus of the amygdala following both fear conditioning and following the presentation of a conditioned-fear stimulus [33]. Another study reported only very small increases in the basolateral nucleus of the amygdala with fear conditioning [3].

Although the expression of c-fos mRNA and Fos protein is increased in the amygdala with fear conditioning, the localization of neuronal activity using c-fos expression in nuclei that are specifically part of the fear circuit has not been very satisfying. However, the expression of other IEGs may display different patterns of neuronal activity than c-fos and have a better relationship to neuronal activation during learning and conditioning. For example, NGFIA (also called zif268, krox-24, egr-1, TIS-8) expression seems to correlate better with long-term potentiation in the hippocampus [1,34,41,42] and visual paired associative learning in the anterior temporal lobe [30] than c-fos does.

The present study was designed to compare the specific patterns of expression of c-fos and NGFI-A mRNA in the amygdala $15 \mathrm{~min}$ following contextual fear conditioning and following a retention test $24 \mathrm{~h}$ after the conditioning. In situ hybridization was used to localize the expression of the two IEGs to specific amygdala nuclei. To test whether the expression of the IEGs was specifically associated with fear conditioning or was merely activated by the aversive unconditioned stimulus (footshock), the well-characterized phenomenon called the immediate-shock freezing deficit was used $[5,11,12]$. If a rat receives footshock immediately upon placement in a chamber, it does not display a postfootshock freezing response nor a contextually conditioned fear response when reintroduced into the chamber $24 \mathrm{~h}$ later. This contrasts with the behavior of a rat allowed to acclimate to the chamber by delaying the footshock delivery for $1 \mathrm{~min}$ or more. This rat displays post-footshock freezing and retention of the contextual fear conditioning (freezing) when returned to the chamber $24 \mathrm{~h}$ later. Therefore, while both rats receive the same footshock, only one displays fear-induced freezing.

The following experiment analyzes the expression of c-fos and NGFI-A mRNA in the amygdala with the immediate-shock freezing deficit paradigm. Rats were either handled, placed in a novel chamber, or received either immediate or delayed footshock. The IEG expression was analyzed either $15 \mathrm{~min}$ following the footshock or $15 \mathrm{~min}$ after being returned to the chamber $24 \mathrm{~h}$ after the footshock.

\section{Materials and methods}

\subsection{Animals}

A total of 72 male Long-Evans rats derived and reared at the UCLA Psychology Department vivarium and weighing approximately $250 \mathrm{~g}$ were used. They were housed individually in wire cages in the UCLA vivarium. Food and water were freely available. A 12-h day/night cycle was maintained throughout the experiment. The animals were tested in the light cycle.

\subsection{Apparatus}

Environmental training and behavioral testing occurred in 4 identical observation chambers (Lafayette Instruments, Lafayette, IN) measuring $28 \times 21 \times 22 \mathrm{~cm}$. The sides of the chambers were made of aluminum but the remaining walls were all composed of clear acrylic plastic. The floor was a grid composed of 18 parallel stainless steel rods (4 $\mathrm{mm}$ in diameter) spaced $1.5 \mathrm{~cm}$ apart (center to center). Each chamber was placed in an open box to screen it from the other observation chambers but allowed video monitoring of the rats from an adjacent room. The room was well lit by overhead fluorescent lamps and ventilation fans provided a background noise level of $70 \mathrm{~dB}$ (A scale). The observation chambers and the stainless steel catch pans were cleaned with a deodorizing $5 \%(\mathrm{v} / \mathrm{v})$ ammonium hydroxide and water solution. The grid floor could be electrified by a high voltage, high resistance AC source that was connected to a mechanical scrambler (Lafayette Instruments).

\subsection{Behavioral procedures}

The experiments were conducted 3 times with 24 rats in each experiment. All rats were handled for about $1 \mathrm{~min}$ every day for 7 days prior to the experiment. They were then divided into 4 conditions termed handled $(n=12)$, context-no-footshock $(n=12)$, immediate-footshock ( $n=$ 24) and delayed-footshock $(n=24)$. The handled rats served as controls and were not placed in the testing chamber. Rats in the context-no-footshock group were placed in the testing chamber for $5 \mathrm{~min}$ and then returned to their home cages. The immediate-footshock rats were placed in the testing chamber and immediately given a $1 \mathrm{~s}$, $1 \mathrm{~mA}$ footshock and left in the chamber for $5 \mathrm{~min}$. They were then returned to their home cages. The delayedfootshock rats were placed in the testing chamber, and were given a $1 \mathrm{~s}, 1 \mathrm{~mA}$ footshock after $1 \mathrm{~min}$. They remained in the chamber for an additional $4 \mathrm{~min}$ and then returned to their home cages.

Half of the rats in the immediate- and delayed-footshock groups were sacrificed by decapitation $15 \mathrm{~min}$ after the footshock. Half of the context-no-footshock rats were decapitated 15 min after being placed in the testing chamber. 
Table 1

Percent of time spent freezing in post-footshock period and retention test

\begin{tabular}{llc}
\hline Footshock condition & Median percentage freezing & Mean \pm S.E.M. percentage freezing \\
\hline Delayed footshock $(n=19)$ & 9 & $33.7 \pm 7.3$ \\
Immediate footshock $(n=19)$ & 0 & $1.3 \pm 0.7$ \\
No footshock $(n=11)$ & 0 & $0.3 \pm 0.2$ \\
\hline
\end{tabular}

The data are the combined results of the post-footshock period and the retention test.

Also half of the handled rats were removed from their home cages and immediately killed. The other rats had a retention test (except the handled rats) $24 \mathrm{~h}$ later. They were placed in the experimental chamber for $5 \mathrm{~min}$ and then returned to their home cages. They were decapitated 10 min later.

Freezing behavior was sampled during the postfootshock period and retention test. Every $2 \mathrm{~s}$, a rat was scored to be freezing or not, thus, each rat was observed once every $8 \mathrm{~s}$. The percentage of samples scored as freezing over the observation period was calculated for each rat. Group differences in the time spent freezing were compared using a Kruskal-Wallis test followed by a Mann-Whitney $U$-test for individual comparisons.

Following decapitation, the brains were quickly removed, rapidly frozen in $-45^{\circ} \mathrm{C}$ isopentane and stored at $-70^{\circ} \mathrm{C}$. Fifteen $\mu \mathrm{m}$ whole brain coronal sections containing dorsal amygdala, hippocampus, and pyriform and parietal cortices (Plate 28 in the atlas of Paxinos and Watson [31]) were cut on a cryostat and thawed onto chrom-alum gelatinized microscope slides. Two adjacent brain sections were placed on each slide. The slides were stored at $-70^{\circ} \mathrm{C}$ until processed for in situ hybridization of c-fos and NGFI-A mRNAs.

\subsection{In situ hybridization}

In situ hybridization of c-fos and NGFI-A mRNAs was performed on 1 slide ( 2 brain sections) per animal for each mRNA. The procedure was conducted separately for c-fos and NGFI-A mRNAs. However, the 8 experimental groups for each mRNA were processed at the same time with the same reagents and exposed to the same film.

The cRNA probes (riboprobes) were directed against a $900 \mathrm{bp}$ sequence of the c-fos mRNA (gift from T. Curran) or $230 \mathrm{bp}$ sequence of NGFI-A (gift from J. Milbrandt). The riboprobes were labelled with ${ }^{35}$ S-UTP (approximately
$10^{6}$ DPM $\mu \mathrm{g}^{-1}$ ) using Sp6 or T7 RNA polymerase Maxiscript according to manufacturer's instructions (Ambion, Cambridge, MA).

Sections were fixed in $4 \%$ formaldehyde in $1 \times$ phosphate-buffered saline (PBS) and then rinsed in PBS. The sections were then treated with $0.25 \%$ acetic anhydride in $0.1 \mathrm{M}$ triethanolamine for $10 \mathrm{~min}$ at room temperature to reduce nonspecific hybridization of the probes. They were then dehydrated with increasing concentrations of ethanol, defatted in chloroform followed by another ethanol rinse and air dried. ${ }^{35} \mathrm{~S}$-labelled riboprobe $\left(2 \times 10^{6}\right.$ c.p.m. $)$ was added to $100 \mu \mathrm{l}$ of hybridization buffer and applied to each slide containing 2 brain sections. The slides were covered with a glass coverslip and incubated in a humidified box overnight at $56^{\circ} \mathrm{C}$. The hybridization buffer contained $20 \mathrm{mM}$ Tris-HCl (pH 7.4), 50\% formamide, 300 $\mathrm{mM} \mathrm{NaCl}, 1 \mathrm{mM}$ EDTA (pH 8), $1 \times$ Denhardt's, 250 $\mu \mathrm{g} \mathrm{ml}^{-1}$ yeast total RNA, $250 \mu \mathrm{g} \mathrm{ml}^{-1}$ yeast total RNA, $100 \mu \mathrm{g} \mathrm{ml}^{-1}$ salmon sperm DNA, $10 \%$ dextran sulfate, $100 \mathrm{mM}$ dithiothreitol, $0.1 \%$ SDS, and $0.1 \%$ sodium thiosulfate. The next day, the sections were rinsed 4 times for 5 min each in $4 \times$ SSC. They were then treated with 20 $\mu \mathrm{g} \mathrm{ml}^{-1}$ RNAse A (Boerhinger-Mannheim, Indianapolis, IN) in a solution containing $0.5 \mathrm{M} \mathrm{NaCl}, 1 \mathrm{mM}$ EDTA, 10 $\mathrm{mM}$ Tris, $\mathrm{pH} 8$ for $30 \mathrm{~min}$ at room temperature. After rinsing for $5 \mathrm{~min}$ each in decreasing concentrations of $1 \times, 0.5 \times, 0.1 \times \mathrm{SSC}$ at room temperature, they were washed in $0.1 \times \mathrm{SSC} 2$ times for $30 \mathrm{~min}$ at $65^{\circ} \mathrm{C}$. Finally, they were rinsed in increasing concentrations of ethanol containing $300 \mathrm{mM}$ ammonium acetate. They were then exposed to Kodak Biomax MR film for 2 days.

The autoradiograms of in situ hybridization of c-fos and NGFI-A mRNAs were digitized and converted to gray values using a Sierra Scientific CCD video camera with Image program v.1.59 (Wayne Rasband, NIMH) on an Apple PowerMac 7600 and then analyzed with the same program. The Image program was used to subtract back-

Fig. 1. (A) Digitized images of c-fos mRNA expression 15 min following footshock. In this figure and in Figs. 2-4, the coronal sections of the brain correspond to Plate 28 of the atlas of Paxinos and Watson. Cingulate $(\mathrm{Cg})$, parietal (Pr) and pyriform (Py) cortices displayed increased c-fos mRNA expression in the context-no-footshock, immediate- and delayed-footshock groups compared to the handled group. The arrows point to the medial nucleus of the amygdala, where there were more specific differences between the groups. (B) Graphic representation of the mean \pm S.E.M. density of c-fos mRNA expression in the medial nucleus of the amygdala. * Denotes a significant difference in density in the context-no-footshock group compared to the handled group. $* *$ Denotes that the immediate- and delayed-footshock groups were significantly different in density than the handled and context-no-footshock groups. 
ground (2D-rolling ball option) and measure the mean density of pixels within a circumscribed area. After visual inspection for possible differences between groups in sig- nal density within discrete brain areas, it was determined that the levels of c-fos mRNA would be statistically analyzed in the medial nucleus of the amygdala, and the

A

\section{c-fos mRNA Expression 15 minutes After Footshock}

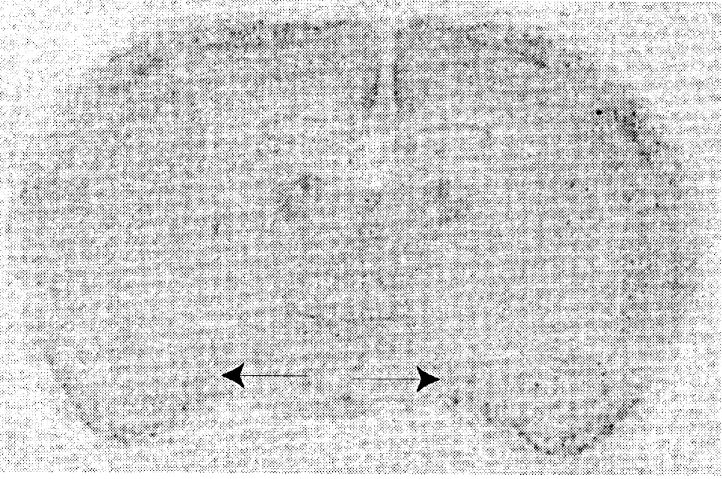

Handled-No Shock

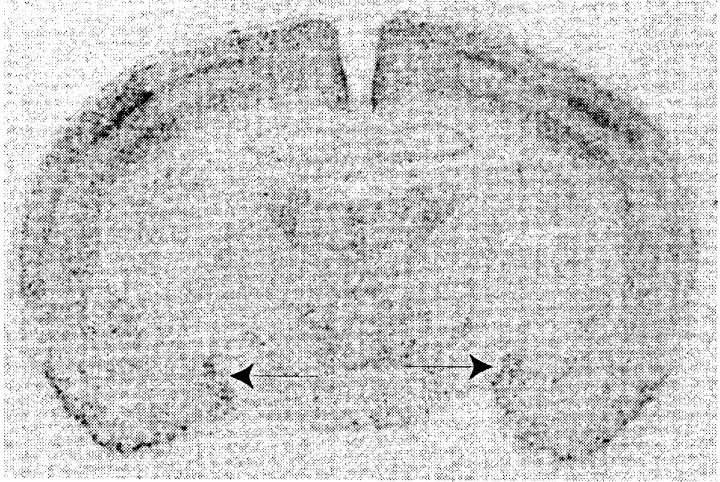

Immediate Shock

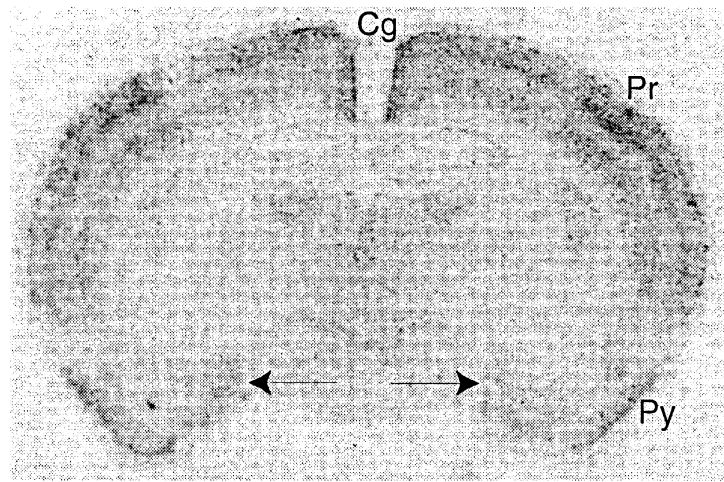

Context-No Shock

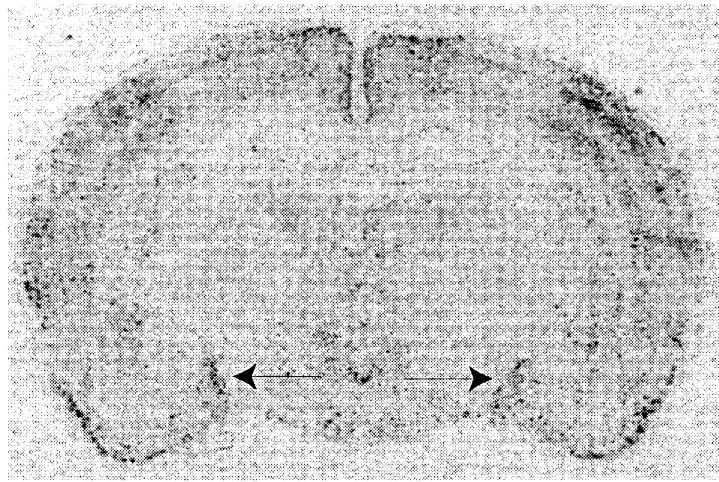

Delayed Shock

B

c-fos mRNA Expression in the Medial Nucleus of the Amygdala 15 Minutes After Footshock

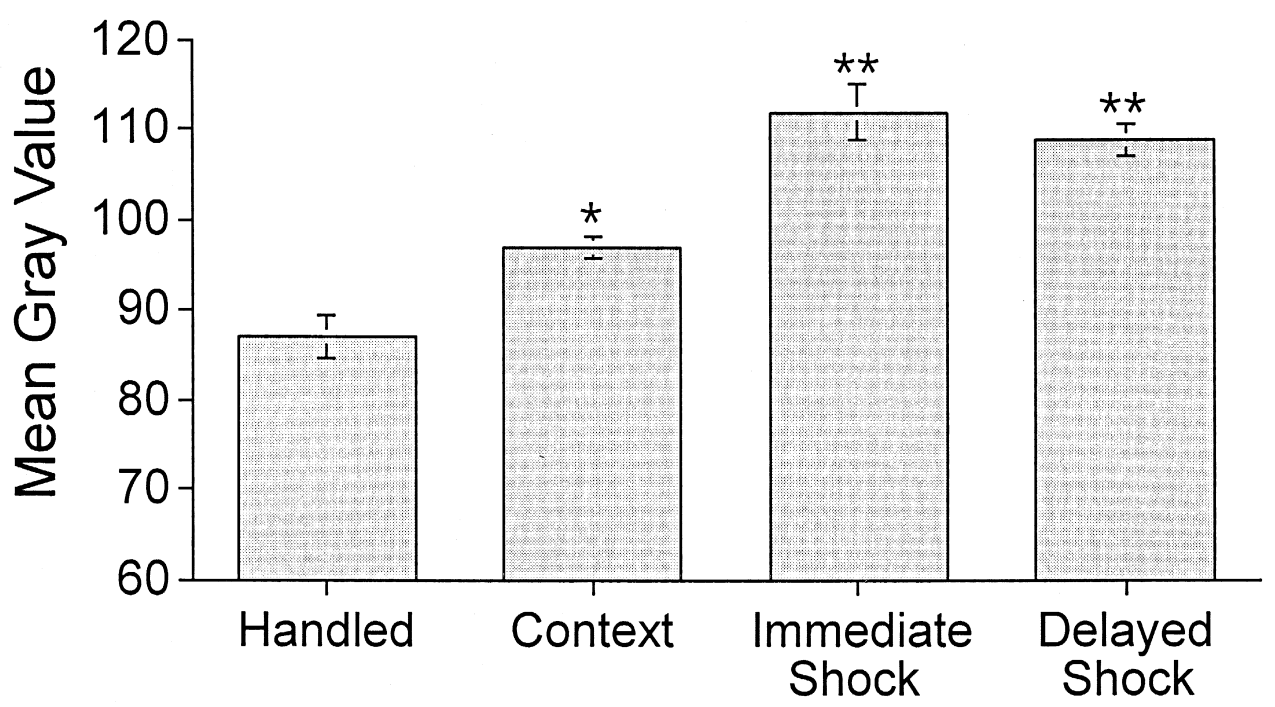


cingulate, parietal and pyriform cortices, whereas the levels of NGFI-A mRNA would only be analyzed in the lateral nucleus of the amygdala. For each region analyzed, the sizes of the areas measured for individual rats were all within $25 \%$ of each other, so that any differences reflected differences in mean gray values in comparable regions. Brains that did not reach this criterion or did not contain the appropriate area were not used in the analysis. Of the brains used for analysis (handled $=9$, context-nofootshock $=11$, immediate-footshock $=19$, delayedfootshock $=19$ ), the densities of the right and left side of the brain for the 2 brain sections per animal were averaged into a single score for each rat. The optical density was compared to ${ }^{14} \mathrm{C}$ standards to assure that the radiographic signals were in the linear portion of the photochemical response of the film. One-way ANOVAs were performed to test for statistically significant overall difference between groups. This was followed by a Scheffe's $S$ test.

\section{Results}

\subsection{Behavior}

Rats that received shock $1 \mathrm{~min}$ after placement showed low but significant levels of freezing conditioned by the single brief shock (see Table 1). By contrast, as is typical with this procedure, rats that received no shock showed virtually no freezing. Rats that received shock immediately upon placement in the chamber behaved like the nofootshock animals. This pattern of results confirms the immediate-shock freezing deficit that has been reported previously (e.g., $[10,11])$.

The level of freezing behavior in each experimental condition was the same in both the post-footshock period and during the retention test. The scores from both tests were therefore grouped for statistical analysis. Since only the delayed-footshock rats showed freezing, there was appreciable heterogeneity of variance and the data were analyzed nonparametrically. Median levels of freezing are presented in Table 1. An overall Kruskal-Wallis test showed the groups to be reliably different, $H(2)=28.6$, $p<0.0001$. Pairwise comparisons made with the MannWhitney $U$-test showed that the delayed-footshock rats were reliably different from the immediate-footshock, $U(19,19)=23, p<0.0001$, and no-footshock, $U(19,11)=$ $2, p<0.0001$, groups. The immediate-footshock and the no-footshock groups did not differ from each other $U(19,11)=97, p>0.7$.

\section{2. c-fos mRNA expression}

\subsubsection{Fifteen minutes post-footshock period}

The expression of c-fos mRNA was analyzed in 24 rats, 6 in each experimental group. The expression was quite widespread in the coronal sections analyzed (Fig. 1a). These included widespread areas of the cortex, thalamus and hypothalamus. Compared to the handled controls, c-fos mRNA expression was elevated in many brain regions in the context-no-footshock, immediate-footshock and delayed-footshock groups. These included the cingulate, parietal and pyriform cortex (Fig. 1a; statistics not shown). Nevertheless, there were no differences between the context-no-footshock, immediate- and delayedfootshock groups in the levels of c-fos mRNA in any of these cortical regions. The c-fos mRNA in the hippocampus was not elevated over the handled group in any group. In the amygdala, the only discernible nucleus with consistent c-fos mRNA expression was the medial nucleus. A one-way ANOVA demonstrated that there was a between group effect $(F(3,20)=25.9, p<0.0001)$. Post-hoc analysis with a Scheffe's $S$ test revealed medial nucleus c-fos levels of the context-no-footshock, and immediate- and delayed-footshock groups were each different from the handled control group c-fos levels (handled vs. contextno-footshock, $p<0.05$; handled vs. immediate-footshock, $p<0.0001$; handled vs. delayed-footshock, $p<0.0001$ ). In addition, the immediate-footshock and delayedfootshock groups had different levels than the context-nofootshock group (context-no-footshock vs. immediatefootshock, $p<0.01$; context-no-footshock vs. delayedfootshock, $p<0.001)$. However, the immediate-footshock and the delayed-footshock c-fos levels were not significantly different (Fig. 1a,b).

\subsubsection{Twenty-four hours post-footshock retention test}

Twenty-three rats were used for this analysis (6 per group, except for the delayed-footshock which had 5). The expression of c-fos mRNA in the cingulate, parietal and pyriform cortices, was significantly greater in the contextno-footshock, and immediate- and delayed-footshock groups compared to the handled groups after the $24 \mathrm{~h}$ retention test (Fig. 2a; statistics not shown), similar to what was found after the $15 \mathrm{~min}$ post-footshock period. In contrast, there were no group differences in the levels of c-fos mRNA expression in the medial nucleus of the amygdala after the $24 \mathrm{~h}$ retention test, $F(3,19)<1$, n.s. (Fig. 2a,b). A comparison of the 15 min post-footshock and $24 \mathrm{~h}$ retention test for each group revealed that c-fos mRNA levels in the medial nucleus of the immediate- and delayed-footshock groups were higher in the 15 min postfootshock period than that after the $24 \mathrm{~h}$ retention test (immediate-footshock: $15 \mathrm{~min}$ post-footshock vs. $24 \mathrm{~h}$ retention, $p<0.001$; delayed-footshock: $15 \mathrm{~min}$ postfootshock vs. $24 \mathrm{~h}$ retention, $p<0.003$ ). Thus, whereas c-fos mRNA levels were increased in the medial nucleus of the amygdala in the 15 min post-footshock period in both the immediate- and delayed-footshock groups, the levels were no different from the handled and context-nofootshock levels after the $24 \mathrm{~h}$ retention test. 
A c-fos mRNA Expression Following Retention Test

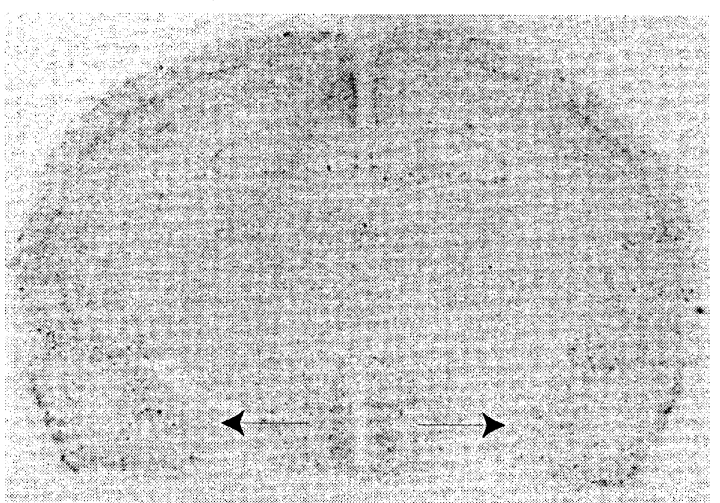

Handled-No Shock

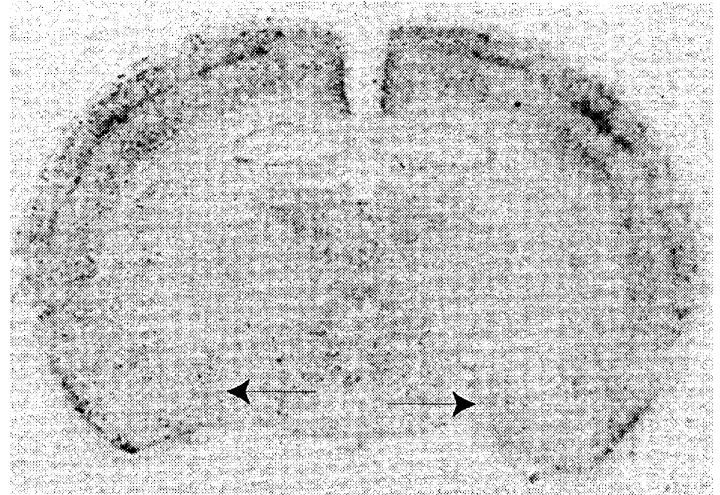

Immediate Shock

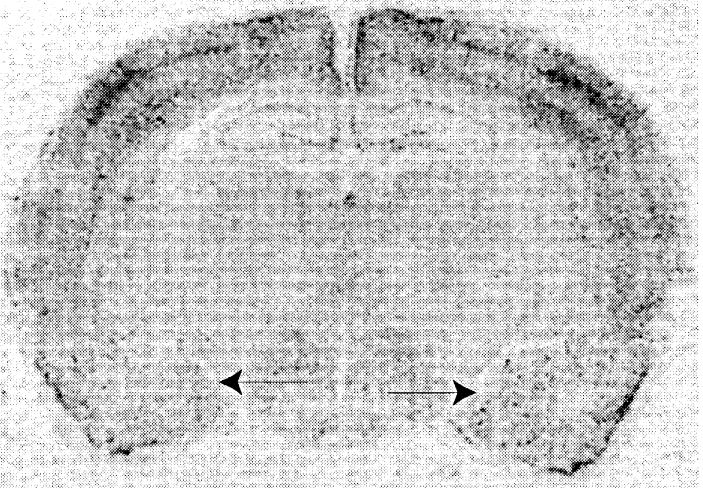

Context-No Shock

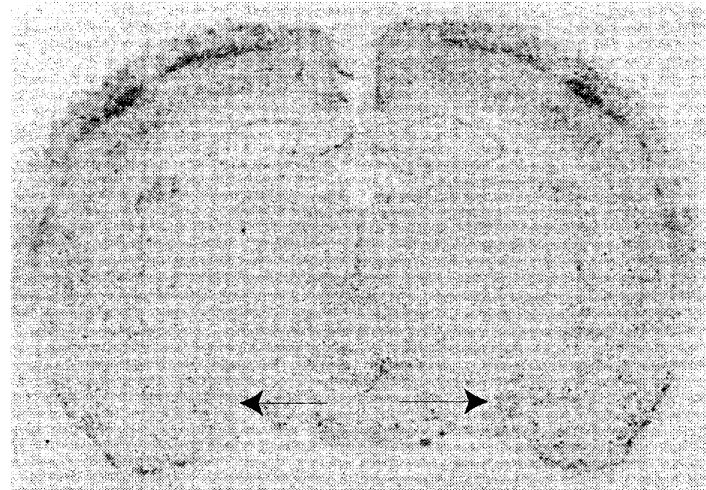

Delayed Shock

B

c-fos mRNA Expression in the Medial Nucleus of the Amygdala Following Retention Test

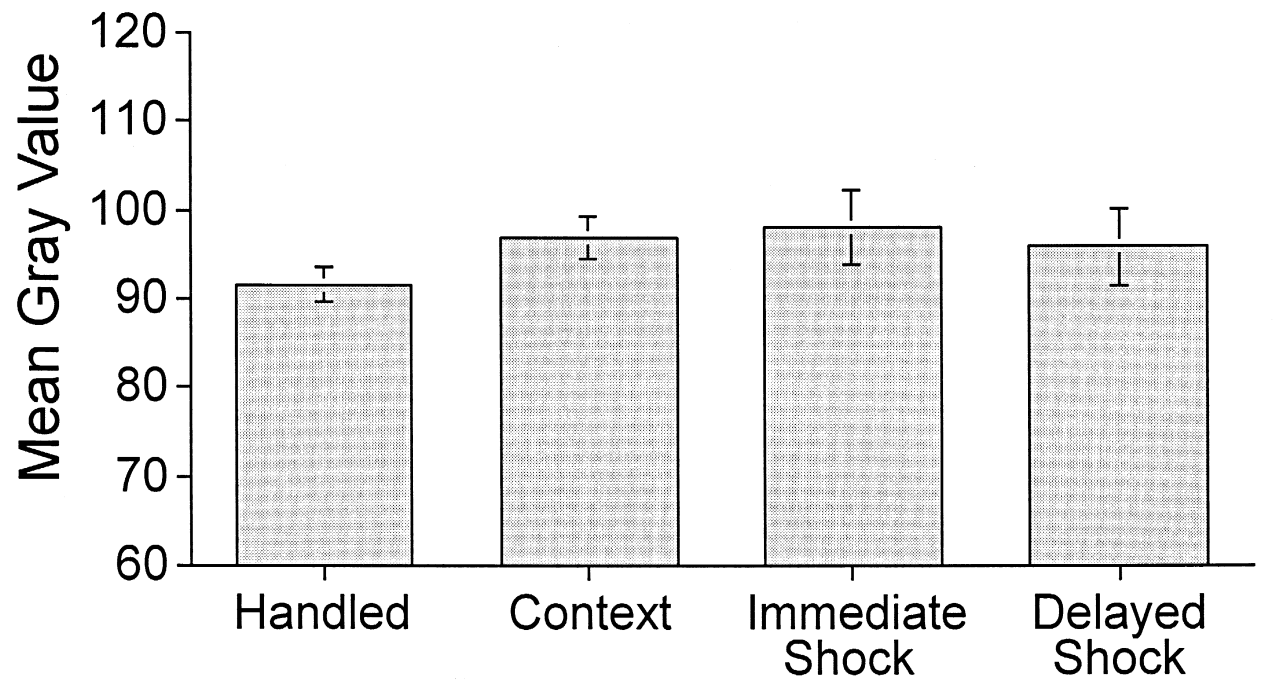

Fig. 2. (A) Digitized images of c-fos mRNA expression after the retention test. The arrows point to the medial nucleus of the amygdala. (B) Graph shows that mean \pm S.E.M. c-fos mRNA expression in the medial nucleus was not different in any of the groups. 
A

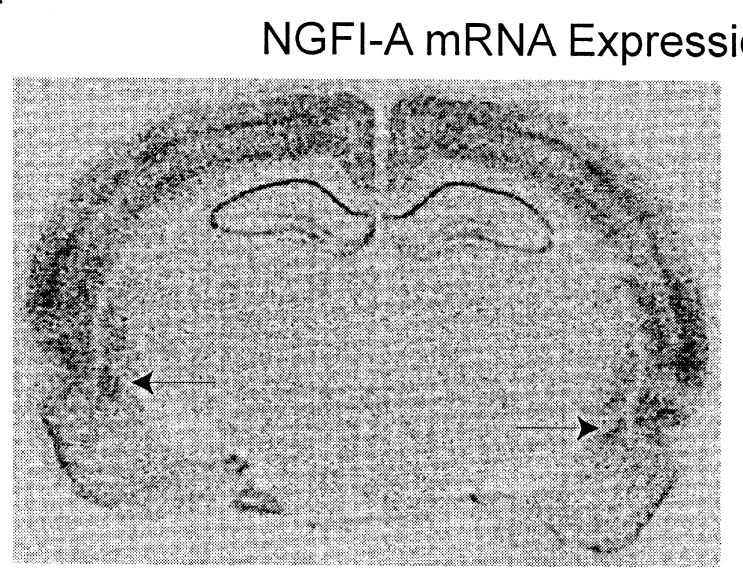

\section{Handled-No Shock}

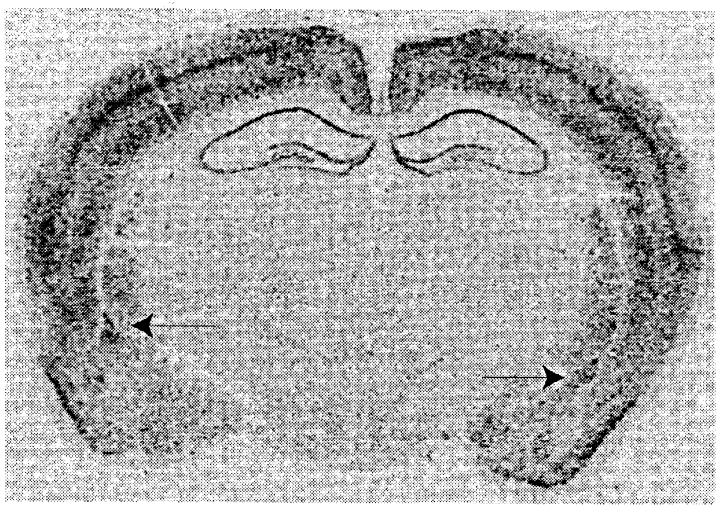

Immediate Shock

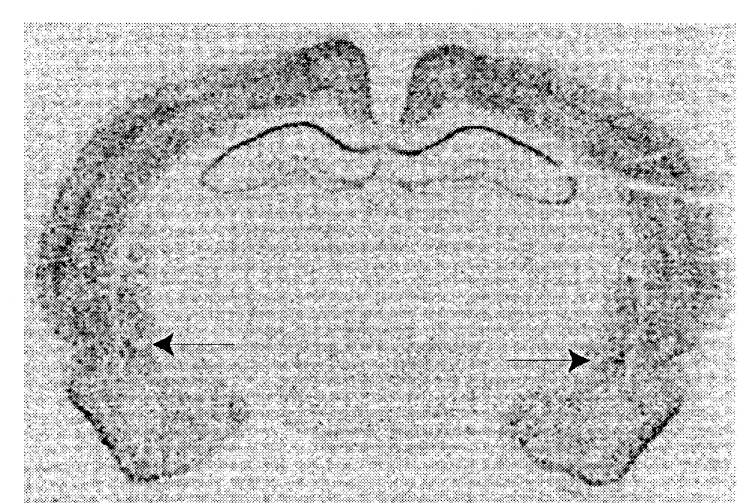

Context-No Shock

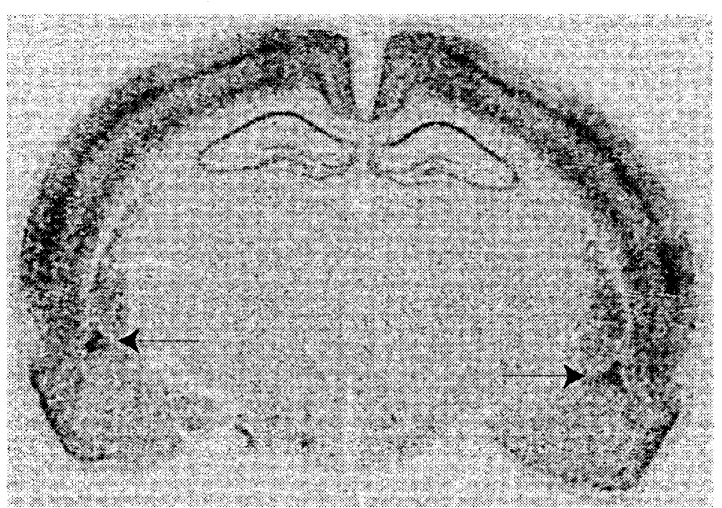

Delayed Shock

B

NGFI-A mRNA Expression in the Lateral Nucleus of the Amygdala 15 Minutes After Footshock

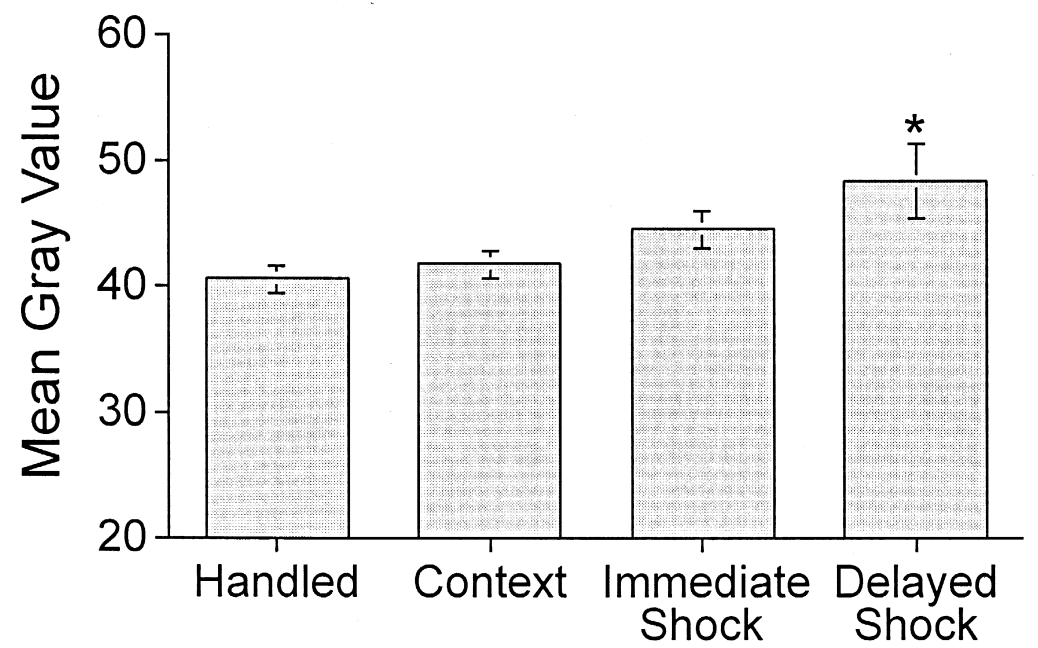

Fig. 3. (A) Digitized images of NGFI-A mRNA expression $15 \mathrm{~min}$ following footshock. The arrows point to the lateral nucleus of the amygdala. (B) Graphic representation of mean \pm S.E.M. NGFI-A mRNA expression in the lateral nucleus of the amygdala. *Denotes that only the delayed footshock group differed from the handled and context-no-footshock groups. 
A

NGFI-A mRNA Expression Following Retention Test

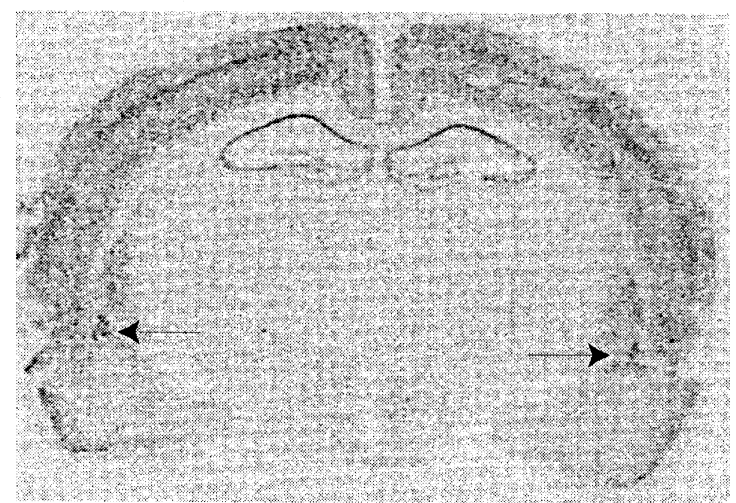

Handled-No Shock

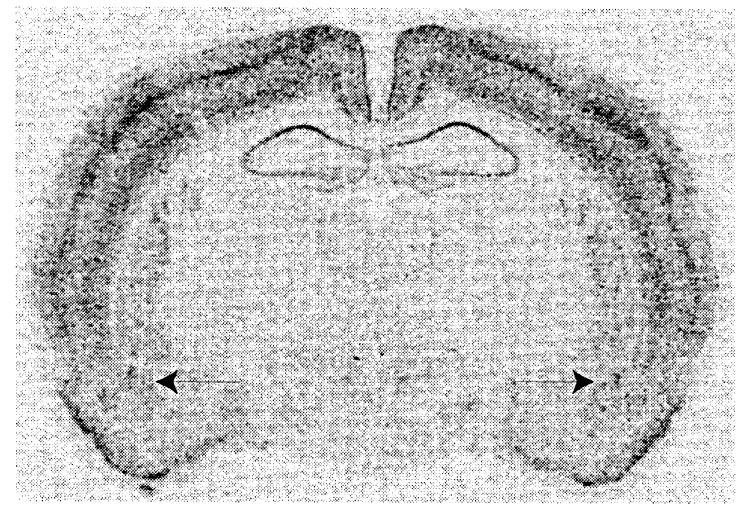

Immediate Shock

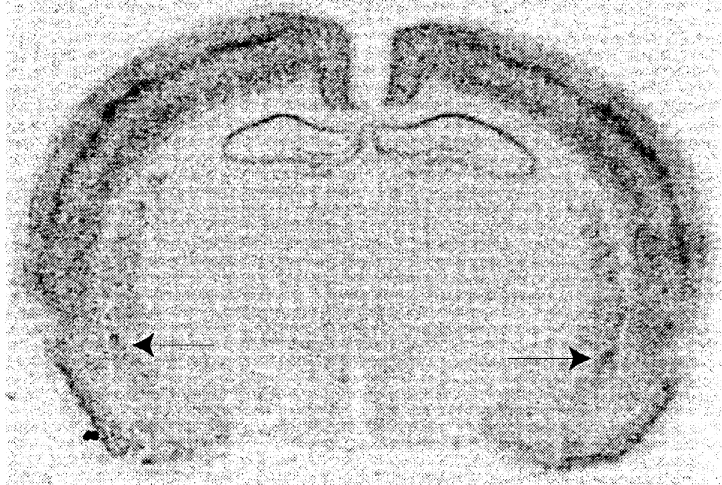

Context-No Shock

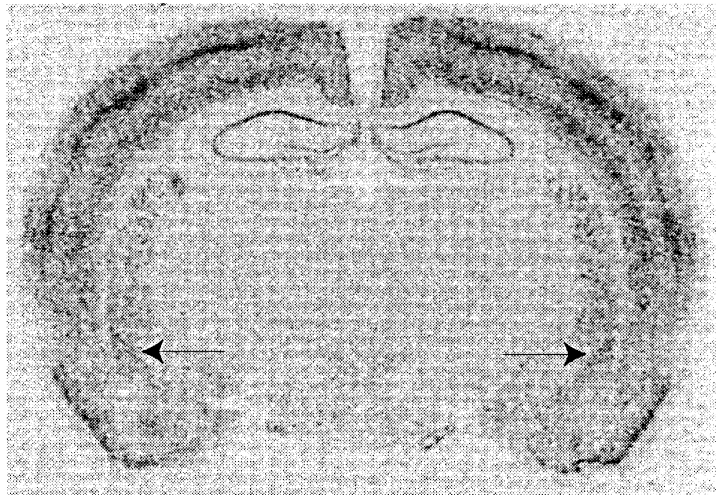

Delayed Shock

B

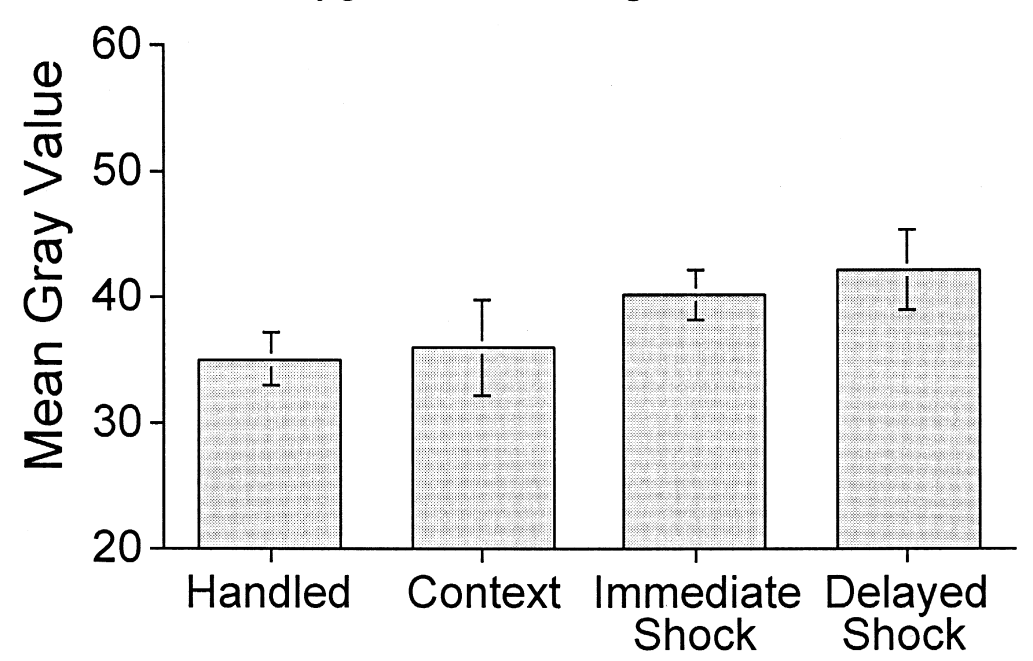

Fig. 4. (A) Digitized images of NGFI-A mRNA expression after the retention test. The arrows point to the lateral nucleus of the amygdala. (B) Graph shows that the mean \pm S.E.M. NGFI-A mRNA expression in the medial nucleus was not different in any of the groups. 


\subsection{NGFI-A mRNA expression}

\subsubsection{Fifteen minutes post-footshock}

Thirty-one rats were used for this analysis (handled $=5$; context-no-footshock $=6$; immediate-footshock $=10$; delayed-footshock $=10$ ). NGFI-A mRNA expression was very widespread. However, visual inspection of the films suggested that the only differences between groups in the coronal sections analyzed were in the lateral nucleus of the amygdala. Therefore, gray values of NGFI-A mRNA labelling were measured only in this nucleus (Fig. 3a,b). Because the NGFI-A mRNA levels of the handled and context-no-footshock groups in the lateral nucleus of the amygdala were not different, their values were combined for statistical analysis. A one-way ANOVA revealed a statistically significant main effect $(F(2,28)=4.3, p<$ $0.02)$. A post-hoc analysis with Scheffe's $S$ test demonstrated a significant difference between the combined control group and the delayed-footshock group $(p<0.02)$. The immediate-footshock group was not statistically different from the combined control or delayed-footshock group.

\subsubsection{Twenty-four hours post-footshock retention test}

Twenty-seven rats were used for this analysis (handled $=4$; context-no-footshock $=5$; immediate-footshock $=9$; delayed-footshock $=9$ ). Similar to c-fos mRNA expression in the medial nucleus, re-exposure to the footshock chamber $24 \mathrm{~h}$ following the footshock did not induce an increase in NGFI-A mRNA levels in the lateral nucleus of the amygdala $(F(3,23)=1.2$, ns; Fig. 4a,b). Visual inspection of other brain regions did not reveal any discernible differences between conditions.

\section{Discussion}

The results demonstrate that there is selective activation of the two IEGs, c-fos and NGFI-A, in the amygdala and cortex of rats experiencing the various conditions of the experiment. In general, c-fos mRNA was expressed in several cortical areas and the medial nucleus of the amygdala during a novel experience, whereas increase in NGFIA mRNA expression in the lateral nucleus of the amygdala was more specific to the contextual fear conditioning experience.

The expression of c-fos mRNA was not associated with fear conditioning. Increases in expression $15 \mathrm{~min}$ after being placed in the chamber or receiving footshock were found in several cortical regions, including the parietal, cingulate and pyriform cortices in the context-no-footshock, immediate-footshock and delayed-footshock groups. Because the levels of expression did not differ between these group conditions, but did differ from the handled group, the increase in expression in the cortex is probably due to the change in the handling routine or being placed in a novel environment. It was not specific to a particular manipulation. In contrast, only part of the increase in the medial nucleus of the amygdala can be attributed to a change in routine or being placed in a novel environment. Whereas c-fos mRNA levels in the context-no-footshock group significantly differed from the handled group, the levels were further increased in the two shock groups compared to the context-no-footshock group. Thus, levels in expression of c-fos mRNA in the medial nucleus of the amygdala could differentiate between the levels of activation induced by novelty and those induced by footshock. Still, induction of c-fos mRNA in the medial nucleus of the amygdala could not be associated specifically with fear conditioning. Behaviorally, the delayed-footshock group displayed post-footshock and fear-conditioned freezing in the retention test but the immediate-footshock groups did not. Although the two groups behaved differently, there was no difference in the levels of c-fos mRNA between the immediate- and delayed-footshock groups.

All of the effects on c-fos mRNA expression were found $15 \mathrm{~min}$ after the novel or footshock experience and were not evident when the rats were returned to the chamber $24 \mathrm{~h}$ later for the retention test. This suggests that the increase in expression of c-fos mRNA in the medial nucleus of the amygdala is associated with general arousal mechanisms that occur during new experiences. In contrast to our results, Pezzone et al. [33] Fos protein immunoreactivity in the medial nucleus of the amygdala during a fear conditioned retention test. Differences may be due to measurement differences or amount of conditioning. We measured c-fos mRNA using a specific riboprobe for c-fos, whereas Pezzone measured Fos protein immunoreactivity with an antibody that recognizes Fos and Fos-related antigens. Pezzone et al. also used a tone as a conditioned stimulus. In contrast, we did not have a specific conditioned cue in our context conditioning. Finally, we used a one-trial conditioning procedure, while Pezzone et al.'s procedure had more extensive training.

Increase in c-fos mRNA and protein in the medial nucleus of the amygdala occurs during numerous activities, including mating and agonistic behavior [21]. Because c-fos expression in the medial nucleus of the amygdala is common to these socially interactive behaviors, KollackWalker and Newman [21] has argued that activation of the medial nucleus of the amygdala may reflect an increase in general arousal. Further indication that the medial nucleus is not specifically involved in fear is a study demonstrating that small lesions confined to the medial nucleus of the amygdala do not interfere with fear conditioning or expression [29]. Our data corroborate this notion since introduction into a novel environment or footshock increased c-fos mRNA expression in the medial nucleus of the amygdala, but the increase was not specific to conditioning as demonstrated by the same c-fos mRNA levels in the immediateand delayed-footshock rats.

In contrast to the medial nucleus of the amygdala, the lateral nucleus may be involved in contextual fear condi- 
tioning. Injections of muscimol, a GABAa agonist, or D,L-2-amino-5-phosphovaleric acid, a NMDA glutamate antagonist, into the basolateral regions of the amygdala (lateral and basolateral nuclei) block contextual fear conditioning $[13,28]$. Thus, the expression of NGFI-A mRNA in the lateral nucleus of the amygdala found in this study is possibly related to contextual fear conditioning. Footshock-induced freezing and freezing during the retention test were found only in the delayed-footshock group, indicating that this group displayed fear following the footshock, whereas the others did not $[4,12,14]$. NGFI-A mRNA expression in the lateral nucleus of the amygdala was significantly increased in the delayed-footshock group compared to the combined handled and context-nofootshock control group. Thus, the increased expression of NGFI-A mRNA expression in the lateral nucleus of the amygdala occurred in the rats that displayed post-footshock freezing. This suggests that NGFI-A mRNA in the lateral nucleus of the amygdala may be a marker for the acquisition of contextual fear conditioning. However, the link between NGFI-A mRNA expression in the lateral nucleus of the amygdala and contextual fear conditioning must be interpreted with caution because the levels of NGFI-A mRNA in the delayed-footshock group were not statistically different from the levels of the immediate-footshock group. Alternatively, this lack of difference between the two footshock groups could be due to the minimal levels of contextual fear conditioning in the delayed-footshock group. The delayed-footshock group displayed freezing only $34 \%$ of the 5 min post-footshock or retention test periods. Stronger fear conditioning may further increase NGFI-A mRNA in the lateral nucleus of the amygdala of the fear conditioned group and reveal a difference in NGFI-A mRNA levels between the two footshock conditions.

The increase of NGFI-A mRNA in the delayedfootshock group was found 15 min after the footshock but not following the retention test $24 \mathrm{~h}$ after the footshock, although the rats displayed significant freezing in the retention test. Therefore, the mechanisms that increased NGFI-A mRNA expression in the lateral nucleus of the amygdala are activated during the acquisition or consolidation of fear learning but not necessarily during the expression of fear behavior.

A role for NGFI-A mRNA in the lateral nucleus of the amygdala in fear conditioning is not clear and can only be postulated at this time. NGFI-A is an immediate-early gene that activates the transcription of other genes, and therefore, may play a role in the cascade of molecular events that participate in the acquisition of fear conditioning. Glutamate NMDA receptors in the lateral nucleus of the amygdala are necessary for the acquisition of fear conditioning $[8,13,26,27]$. Glutamate also activates that expression of NGFI-A mRNA through NMDA receptors [2,43]. Therefore, during fear conditioning, glutamate release and activation of the NMDA receptor may activate NGFI-A expression. NGFI-A may then increase the expression of other genes [32,38] which may be important for greater neuronal responses in the lateral nucleus of the amygdala and the formation of long-lasting memories that are a consequence of the fearful experience.

\section{Acknowledgements}

This work was supported by NSF Grant IBN-9723295 to MSF.

\section{References}

[1] W.C. Abraham, M. Dragunow, W.P. Tate, The role of immediateearly genes in the stabilization of long-term potentiation, Mol. Neurobiol. 5 (1991) 297-314.

[2] H. Bading, M.M. Segal, N.J. Sucher, H. Dudek, S.A. Lipton, M.E. Greenberg, $N$-methyl-D-aspartate receptors are critical for mediating the effects of glutamate on intracellular calcium concentration and immediate gene expression in cultured hippocampal neurons, Neuroscience 64 (1995) 653-664.

[3] C.H. Beck, H.C. Fibiger, Conditioned fear-induced changes in behavior and in the expression of the immediate-early gene c-fos: with and without diazepam pretreatment, J. Neurosci. 15 (1995) 709-720.

[4] D.C. Blanchard, R.J. Blanchard, Crouching as an index of fear, J. Comp. Physiol. Psychol. 67 (1969) 370-375.

[5] R.J. Blanchard, K.K. Fukanaga, D.C. Blanchard, Environmental control of defensive reactions to footshock, Bull. Psychon. Soc. 8 (1976) 129-130.

[6] S. Campeau, M. Davis, Involvement of the central and basolateral complex of the amygdala in fear conditioning measured with fearpotentiated startle in rats trained concurrently with auditory and visual conditioned stimuli, J. Neurosci. 15 (1995) 2301-2311.

[7] S. Campeau, M.D. Hayward, B.T. Hope, J.B. Rosen, M. Davis, Induction of the c-fos proto-oncogene in rat amygdala during unconditioned and conditioned fear, Brain Res. 565 (1991) 349-352.

[8] S. Campeau, M.J. Miserendino, M. Davis, Intra-amygdala infusion of the $N$-methly-D-aspartate receptor anatagonist AP5 blocks acquisition but not expression of fear-potentiated startle to an auditory conditioned stimulus, Behav. Neurosci. 106 (1992) 469-574.

[9] M. Davis, The role of the amygdala in conditioned fear, in: J.P. Aggleton (Ed.), The amygdala: neurobiological aspects of emotion, memory and mental dysfunction, Wiley-Liss, New York, 1992, pp. 255-306.

[10] M.S. Faneslow, Factors governing one-trial contextual conditioning, Anim. Learn. Behav. 18 (1990) 264-270.

[11] M.S. Fanselow, Associative vs. topographical accounts of the immediate-shock freezing deficit in rats: implication for the response selection rules governing species-specific defensive reactions, Learn. Motiv. 17 (1986) 16-39.

[12] M.S. Fanselow, Neural organization of the defensive behavior system responsible for fear, Psychon. Bull. Rev. 1 (1994) 429-438.

[13] M.S. Fanselow, J.J. Kim, Acquisition of contextual Pavlovian fear conditioning is blocked by application of an NMDA receptor antagonist D,L-2-amino-5-phosphonovaleric acid to the basolateral amygdala, Behav. Neurosci. 108 (1994) 210-212.

[14] F.J. Helmstetter, M.S. Fanselow, Conditional analgesia, defensive freezing, and benzodiazepines, Behav. Neurosci. 102 (1988) 233243.

[15] J.M. Hitchcock, M. Davis, Lesions of the amygdala, but not the cerebellum or red nucleus, block conditioned fear as measured with the potentiated startle paradigm, Behav. Neurosci. 100 (1986) 11-22. 
[16] D.A. Hopkins, G. Holstege, Amygdaloid projections to the mesencephelon, pons, and medulla oblongata in the cat, Exp. Brain Res. 32 (1978) 529-547.

[17] J. Iwata, K. Chida, J.E. LeDoux, Cardiovascular response elicited by stimulation of neurons in the central amygdaloid nucleus in awake but not anesthetized rats resemble conditioned emotional responses, Brain Res. 418 (1987) 183-188.

[18] B.S. Kapp, R.C. Frysinger, M. Gallagher, C.D. Applegate, Amygdala central nucleus lesions: effects on heart rate conditioning in the rabbit, Physiol. Behav. 23 (1979) 1109-1117.

[19] B.S. Kapp, M. Gallagher, M.D. Underwood, C.L. McNall, D. Whitehorn, Cardiovascular responses elicited by electrical stimulation of the amygdala central nucleus in the rabbit, Brain Res. 234 (1982) 251-262.

[20] M. Kim, S. Campeau, W.A. Fall, M. Davis, Infusion of the nonNMDA receptor antagonist CNQX into the amygdala blocks the expression of fear-potentiated startle, Behav. Neur. Biol. 59 (1993) $5-9$.

[21] S. Kollack-Walker, S.W. Newman, Mating and agonistic behavior produce different patterns of Fos immunolabelling in the male syrian hamster brain, Neuroscience 66 (1995) 721-736.

[22] J.E. Krettek, J.L. Price, Amygdaloid projections to subcortical structures within the basal forebrain and brainstem in the rat and cat, J. Comp. Neurol. 78 (1978) 225-254.

[23] J.E. LeDoux, The emotional brain, Simon and Schuster, New York, 1996.

[24] J.E. LeDoux, P. Cicchetti, A. Xagoraris, L.M. Romanski, The lateral amygdaloid nucleus: sensory interface of the amygdala in fear conditioning, J. Neurosci. 10 (1990) 1043-1054.

[25] J.E. LeDoux, M.E. Thompson, C. Iadecola, L.W. Tucker, D.J. Reis, Local cerebral blood flow increases during auditory and emotional processing in the conscious rat, Science 221 (1983) 576-578.

[26] S. Maren, G. Aharonov, D.L. Stote, M.S. Fanselow, N-methyl-Daspartate receptors in the basolateral amygdala are required for both acquisition and expression of conditional fear in rats, Behav. Neurosci. 110 (1996) 1365-1374.

[27] M.J.D. Miserendino, C.B. Sananes, K.R. Melia, M. Davis, Blocking of acquisition but not expression of conditioned fear-potentiated startle by NMDA antagonists in the amygdala, Nature 345 (1990) 716-718.

[28] J. Muller, K.P. Coordimas, Z. Fridel, J.E. LeDoux, Functional inactivation of the lateral and basal nuclei of the amygdala by muscimol infusion prevents fear conditioning to an explicit conditioned stimulus and to contextual stimuli, Behav. Neurosci. 111 (1997) 683-691.

[29] M.E. Oakes, G.D. Coover, Effects of small amygdala lesions on fear, but not aggression, in the rat, Physiol. Behav. 61 (1997) 45-55.
[30] H. Okuno, Y. Miyashita, Expression of the transcription factor zif268 in the temporal cortex of monkeys during visual paired associate learning, Eur. J. Neurosci. 8 (1996) 2118-2128.

[31] G. Paxinos, C. Watson, The rat brain in stereotaxic coordinates, 2nd edn., Academic Press, Sydney, 1986.

[32] D. Petersohn, S. Schoch, D.R. Brinkmann, G. Thiel, The human synapsin II gene promoter. Possible role for the transcription factor zif268/egr-1, polyoma enhancer activator 3, and AP2, J. Biol. Chem. 270 (1995) 24361-24369.

[33] M.A. Pezzone, W.S. Lee, G.E. Hoffman, B.S. Rabin, Induction of c-fos immunoreactivity in the rat forebrain by conditioned and unconditioned aversive stimuli, Brain Res. 597 (1992) 41-50.

[34] C.L. Richardson, W.P. Tate, S.E. Mason, P.A. Lawlor, M. Dragunow, W.C. Abraham, Correlation between the induction of an immediate-early gene, zif268 and long-term potentiation in the dentate gyrus, Brain Res. 580 (1992) 147-154.

[35] J.B. Rosen, M. Davis, Enhancement of acoustic startle by electrical stimulation of the amygdala, Behav. Neurosci. 102 (1988) 195-202.

[36] J.B. Rosen, J.M. Hitchcock, C.B. Sananes, M.J.D. Miserendino, M. Davis, A direct projection from the central nucleus of the amygdala to the acoustic startle pathway: Anterograde and retrograde tracing studies, Behav. Neurosci. 105 (1991) 817-825.

[37] M.A. Smith, S. Banerjee, P.W. Gold, J. Glowa, Induction of c-fos mRNA in rat brain by conditioned and unconditioned stressors, Brain Res. 578 (1992) 135-141.

[38] G. Thiel, S. Schoch, D. Petersohn, Regulation of synapsin I gene expression by the zinc finger transcription factor zif268/egr-1, J. Biol. Chem. 269 (1994) 15294-15301.

[39] J.G. Veening, Subcortical afferents of the amygdaloid complex in the rat: An HRP study, Neurosci. Lett. 8 (1978) 196-202.

[40] J.G. Veening, L.W. Swanson, P.E. Sawchenko, The organization of projections from the central nucleus of the amygdala to brainstem sites involved in central autonomic regulation: A combined retrograde transport-immunohistochemical study, Brain Res. 303 (1984) 337-357.

[41] W. Wisden, M.L. Errington, S.B. Dunnett, C. Waters, D. Hitchcock, G. Evan, T.V. Bliss, S.P. Hunt, Differential expression of immediate-early genes in the hippocampus and spinal cord, Neuron 4 (1990) 603-614.

[42] P.F. Worley, R.V. Bhat, J.M. Baraban, C.A. Erickson, B.L. McNaughton, C.A. Barnes, Thresholds for synaptic activation of transcription factors in hippocampus: Correlation with long-term enhancement, J. Neurosci. 13 (1993) 4776-4786.

[43] P.F. Worley, A.J. Cole, D.W. Saffen, J.M. Baraban, Regulation of immediate-early genes in brain: Role of NMDA receptor activation, Prog. Brain Res. 86 (1990) 277-285. 